\title{
Novel complex translocation involving 5 different chromosomes in a chronic myeloid leukemia with Philadelphia chromosome: a case
} report

\author{
Walid Al Achkar*1, Abdulsamad Wafa1,2, Hasmik Mkrtchyan², \\ Faten Moassass ${ }^{1,2}$ and Thomas Liehr ${ }^{2}$
}

\begin{abstract}
Address: ${ }^{1}$ Molecular Biology and Biotechnology Department, Human Genetics Div., Atomic Energy Commission of Syria, P.O. Box 6091, Damascus, Syria and 2Jena University Hospital, Institute of Human Genetics and Anthropology, Kollegiengasse 10, D-07743 Jena, Germany

Email: Walid Al Achkar* - scientific@aec.org.sy; Abdulsamad Wafa - awafa@mail2world.com; Hasmik Mkrtchyan - hamk@mti.uni-jena.de; Faten Moassass -fmoassass@mail2world.com; Thomas Liehr - i8lith@mti.uni-jena.de

* Corresponding author
\end{abstract}

Published: 9 November 2009

Molecular Cytogenetics 2009, 2:21 doi:10.1186/1755-8166-2-2I
Received: 14 September 2009

Accepted: 9 November 2009

This article is available from: http://www.molecularcytogenetics.org/content/2/I/2I

(C) 2009 Al Achkar et al; licensee BioMed Central Ltd.

This is an Open Access article distributed under the terms of the Creative Commons Attribution License (http://creativecommons.org/licenses/by/2.0), which permits unrestricted use, distribution, and reproduction in any medium, provided the original work is properly cited.

\begin{abstract}
Background: The well-known typical fusion gene BCR/ABL can be observed in connection with a complex translocation event in only $2-10 \%$ of cases with chronic myeloid leukemia (CML). As currently most CML cases are treated with Imatinib, variant rearrangements have in general no specific prognostic significance, though the emergence of therapy resistance remains to be studied.

Results: Here we report an exceptional CML case with complex chromosomal aberrations not observed before, involving a 5 chromosome translocation implying chromosomal regions such as $|q 42,4 p| 4$ and $5 q 3 \mid$ besides $9 q 34$ and $22 q|| .2$.
\end{abstract}

Conclusion: The reported rearrangement developed most probably in one initial step and had no influence on a good response during Imatinib treatment.

\section{Introduction}

Chronic myeloid leukemia (CML), a clonal myeloproliferative disease is known to develop from a pluripotent bone-marrow stem cell following the typical BCR and ABL somatic gene rearrangement. In $90-95 \%$ of cases with $\mathrm{CML}$, the $\mathrm{BCR} / \mathrm{ABL}$ fusion gene is the result of reciprocal translocation between chromosomes 9 and 22 and is cytogenetically observable as a small derivative chromosome 22 which is known as Philadelphia (Ph1) chromosome $[1,2]$.

In a Ph-positive CML expression of the BCR/ABL chimeric protein p210 with an increased tyrosine kinase activity is essential for multiple signaling pathways to confer the leukemia phenotype [3]. Imatinib mesylate (Glivec, formerly STI571) was designed specifically to inhibit the tyrosine kinase activity of the bcr/abl protein and other tyrosine kinases such as c-abl, c-kit and platelet-derived growth factor receptor. By binding to an active site of the tyrosine kinase, Imatinib mesylate switches off downstream signaling, cells stop proliferating and apoptosis ensues [4]. Many studies have shown a high efficiency of Imatinib therapy to achieve a complete or major cytogenetic response, i.e. $0-34 \% \mathrm{Ph}$-positive cells. This positive effect may be achieved in cases with simple $t(9 ; 22)$, and complex translocations resulting in a BCR/ABL fusion gene, as well as in cases with cytogenetic clonal evolution $[5,6]$. 
Complex chromosomal rearrangements involving one or more additional chromosomes were described in >600 cases with CML [7]. By conventional cytogenetic analysis, two variant subgroups have traditionally been recognized: complex, $\mathrm{t}(9 ; 22 ; \mathrm{V})$, where $\mathrm{V}$ represents a third translocation partner chromosome and simple, $\mathrm{t}(9 ; \mathrm{V})$ or $\mathrm{t}(22 ; \mathrm{V})$ [8]. Only in a few cases is a chromosomal fragment from the third chromosome translocated to the $\operatorname{der}(22) \mathrm{t}(9 ; 22)$,

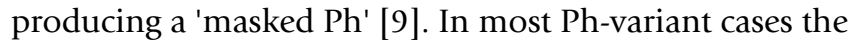
segment 22q11->qter is moved to a third chromosome, while a part of the third chromosome is located on 9q34. Deletions on the derivative chromosome 9 were found to occur with a much higher frequency in patients with variant $\mathrm{Ph}$ translocations (45\%) than in those with classic $\mathrm{Ph}$ $(17 \%)$ [10].

Herein we report on a CML cases with new complex aberrations with five chromosomal breakpoints, nonetheless successfully treatable by Imatinib.

\section{Case report}

The 45 year old female patient presented initially with a whole blood cell count (WBC) of 43.500/l, splenomegaly and severe loss of weight. Chromosome analysis using banding cytogenetics only revealed a karyotype in concordance with the clinical diagnosis of a CML in chronic phase. She was treated with Hydroxyurea (1000 mg daily dose).

Four years and four months later her WBC was $17.61 \times$ $10 \%$ l, i.e. $71.6 \%$ neutrophils, $18.9 \%$ lymphocytes, $3.1 \%$ eosinophiles, $5.1 \%$ monocytes, $0.2 \%$ basophiles. Platelets count was $650 \times 10^{9} / \mathrm{l}$ and hemoglobin $12.1 \mathrm{~g} / \mathrm{dl}$. She was treated with Imatinib (400 mg daily dose) for overall 10

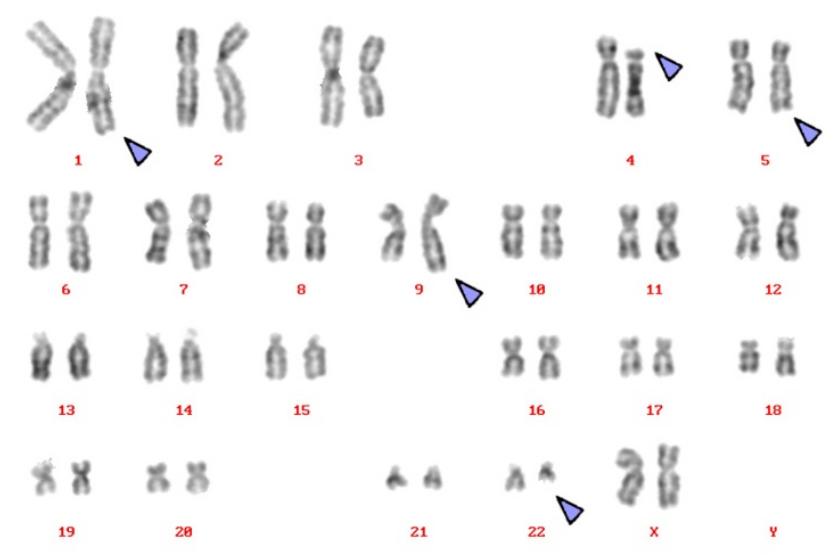

Figure I

GTG-banding revealed a complex karyotype involving three further chromosomes besides chromosomes 9 and 22 . All derivative chromosomes are marker by arrowheads. months. Then her WBC was $27.70 \times 10^{9} /$ liter, i.e. $70.2 \%$ neutrophils, $16.5 \%$ lymphocytes, $5.7 \%$ eosinophiles, $6.6 \%$ monocytes and $0.1 \%$ basophiles. Platelets count was $793 \times 10^{9} / 1$ and hemoglobin $12.7 \mathrm{~g} / \mathrm{dl}$. Serum lactate dehydrogenase (LDH) was $515 \mathrm{U} / \mathrm{l}$ (normal up to $480 \mathrm{U} /$ l), and serum alkaline phosphates was $120 \mathrm{U} / \mathrm{l}$ (normal: up to $90 \mathrm{U} / \mathrm{l})$.

Karyotyping was done again at 3 and 10 months after initiation of Imatinib-treatment, respectively, showing additional karyotypic changes. A complex karyotype 46, XX, $\mathrm{t}(1 ; 4 ; 5 ; 9 ; 22)$ was determined in GTG-banding (Fig. 1) and further studied by molecular cytogenetics (Fig. 2 and Fig. 3). Dual-color-FISH using a commercially available probe specific for BCR and ABL revealed that the typical Philadelphia-chromosome with BCR/ABL-translocation was present. However, parts of chromosome 22 were present on a der(1) (Fig. 2). Thus, array-proven high-resolution multicolor banding (aMCB, Fig. 3), using probes for the corresponding chromosomes involved according to GTG-banding, was done [11]. The following result was obtained: 46, XX, t, $(1 ; 4 ; 5 ; 9 ; 22)(\mathrm{q} 42 ; \mathrm{p} 14 ; \mathrm{q} 31 ; \mathrm{q} 34 ; \mathrm{q} 11.2)$. Thus, it is most likely that the complexity of the karyotype was missed initially due to low chromosomal resolution.

\section{Discussion}

According to the literature, in 2-10\% CML cases the fusion gene $\mathrm{BCR} / \mathrm{ABL}$ is a result of a complex translocation. At

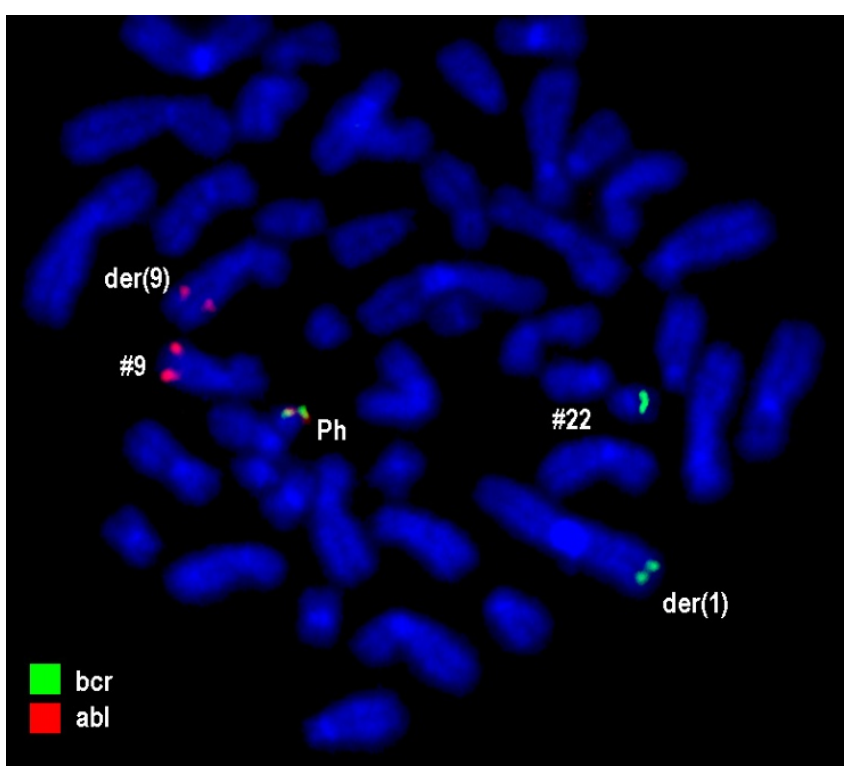

Figure 2

Fluorescence in situ hybridization (FISH) using probes for BCR (green) and ABL (red) confirmed an involvement of chromosome $I$ in the rearrangement present in this case. Abbreviations: \# = chromosome; der $=$ derivative chromosome; $\mathrm{Ph}=$ Philadelphia-chromosome. 


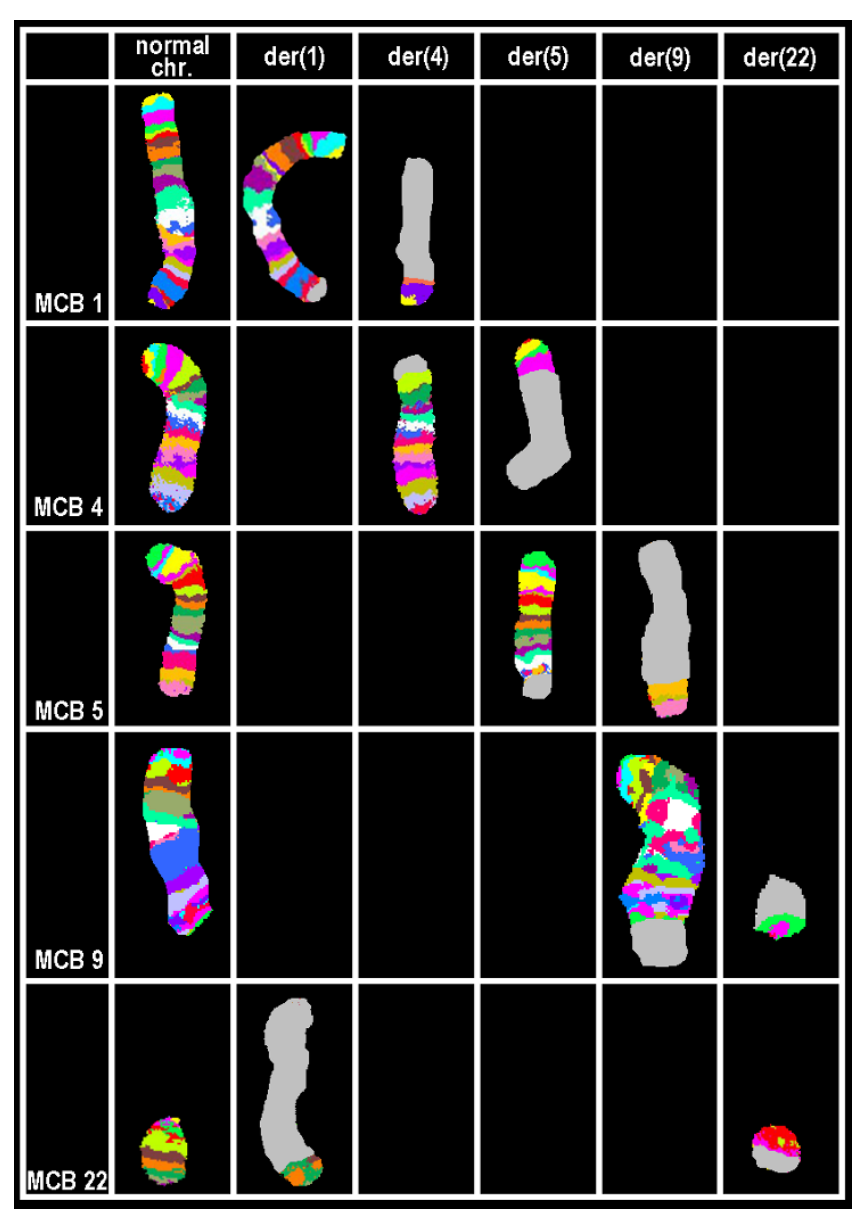

Figure 3

Array-proven multicolor banding (aMCB) was applied to determine the involved in this complex rearrangement. In each lane the results of $\mathrm{aMCB}$ analysis using probe-sets for chromosomes I, 4, 5, 9 and 22 are shown. The normal chromosomes are shown in the first column, the derivative of all five chromosomes in the following ones. In the light gray by aMCB-probes unstained regions on the derivative chromosomes are depicted.

present it appears that variant translocations can affect any chromosome. However, it has been suggested that distribution of the break-points is non-random with the chromosomal bands most susceptible to breakage being: 1p36, 3p21, 5q31, 6p21, 9q22, 10q22, 11q13, 12p13, $17 \mathrm{p} 13,17 \mathrm{q} 21,17 \mathrm{q} 25,19 \mathrm{q} 13,21 \mathrm{q} 22,22 \mathrm{q} 12$ and $22 \mathrm{q} 13$ [7]. In our study we found one out of the three breakpoints to be member of this list, i.e. 5q31. However, the fusion gene remained on chromosome 22.

Two possible mechanisms for variant translocation formation were suggested. The first is a single-event rear- rangement via the simultaneous breakage of several chromosomes followed by mismatched joining [12]. Nacheva et al proposed a classical Ph translocation followed by a further translocation event between chromosomes 9 and 22 plus a third chromosome [13]. The mechanism of the formation of a variant $\mathrm{Ph}$ translocation may have prognostic importance in that a two-event mechanism represents clonal evolution, whereas a variant translocation occurring via a single genomic rearrangement may confer a similar prognosis to the classical $\mathrm{Ph}$ translocation; i.e. clonal evolution has a worse prognosis [14]. According to that, we suggest that the reported patient developed the rearrangement in one initial step and thus, also had such a good response to treatment.

\section{Materials and methods}

Banding cytogenetics using GTG-banding was done according to standard procedures [15]; 20 metaphases derived from unstimulated bone marrow of the patient were analyzed, each.

Fluorescence in situ hybridization (FISH) using commercially available probes for BCR and ABL (Abbott/Vysis) were applied according to manufacturers instructions. High resolution array-proven multicolor-banding (aMCB) based on microdissection derived region-specific libraries for chromosome 1, 4, 5, 9 and 22 was done as described before; method and MCB probe sets are specified $[11,16] .20$ metaphase spreads were analyzed, each using a fluorescence microscope (AxioImager.Z1 mot, Zeiss) equipped with appropriate filter sets to discriminate between a maximum of five fluorochromes and the counterstain DAPI (Diaminophenylindol). Image capturing and processing were carried out using an Isis mFISH imaging system (MetaSystems, Altlussheim, Germany) for the evaluation MCB.

\section{Competing interests}

The authors declare that they have no competing interests.

\section{Authors' contributions}

AW and FM performed the cytogenetic studies in the present case and collected the data relative to this case report. WA supervised the cytogenetic analysis as Director of the MBBD. HM, AW, FM TL did the molecular cytogenetic analysis and interpretation. TL drafted the paper and all authors contributed to the finalizing of the manuscript.

\section{Consent}

Written informed consent was obtained from the patient for publication of this case report and accompanying images. A copy of the written consent is available for review by the Editor-in-Chief of this journal. 


\section{Acknowledgements}

We would like to thank Prof. Ibrahim Othman, the Director General of Atomic Energy Commission of Syria (AECS), and Dr. Nizar MirAli, Head of Molecular Biology and Biotechnology Department, for their support.

This work was supported by the AECS, in parts by the Stefan-Morsch-Stiftung, Monika-Kutzner-Stiftung and the DAAD (D/07/09624).

\section{References}

I. Rooney DE: Human Cytogenetics Malignancy and Acquired Abnormalities. 3rd edition. Oxford University Press, New York; 200I:37.

2. Sessions J: Chronic myeloid leukemia in 2007. Am J Health Syst Pharm 2007, 64:S4-9.

3. Lugo T, Pendergast A, Müller A, Witte O: Tyrosine kinase activity and transformation potency of bcr-abl oncogene products. Science 1990, 247: 1079-1082.

4. Griffen J: The biology of signal transduction The biology of signal transduction inhibition: basic science to novel therapies. Semin Oncol 200I, 28:3-8.

5. Kantarjian H, Sawyers C, Hochhaus A, Guilhot F, Schiffer C, Gambacorti-Passerini C, Niederwieser D, Resta D, Capdeville R, Zoellner U, Talpaz M, Druker B, Goldman J, O'Brien SG, Russell N, Fischer T, Ottmann O, Cony-Makhoul P, Facon T, Stone R, Miller C, Tallman M, Brown R, Schuster M, Loughran T, Gratwohl A, Mandelli F, Saglio G, Lazzarino M, Russo D, Baccarani M, Morra E: Hematologic and cytogenetic responses to imatinib mesylate in chronic myelogenous leukemia. N Engl J Med 2002, 346:645-652.

6. Cortes JE, Talpaz M, Giles F, O'Brien S, Rios MB, Shan J, Garcia-Manero G, Faderl S, Thomas DA, Wierda W, Ferrajoli A, Jeha S, Kantarjian HM: Prognostic significance of cytogenetic clonal evolution in patients with chronic myelogenous leukemia on imatinib mesylate therapy. Blood 2003, I01:3794-3800.

7. Johansson B, Fioretos T, Mitelman F: Cytogenetic and molecular genetic evolution of chronic myeloid leukemia. Acta Haematol 2002, 107:76-94.

8. Huret JL: Complex translocations, simple variant translocations and Ph-negative cases in chronic myelogenous leukaemia. Hum Genet 1990, 85:565-568.

9. Hagemeijer A, de Klein A, Godde-Salz E, Turc-Carel C, Smit EME, van Aghtoven AJ, Grosveld GC: Translocation of c-abl to 'masked' $\mathbf{P h}$ in chronic myeloid leukemia. Cancer Genet Cytogenet 1985, 1 8:95-104.

10. Reid A, Gribble SM, Huntly BJ, Andrews KM, Campbell L, Grace CD, Wood ME, Green AR, Nacheva EP: Variant Philadelphia translocations in chronic myeloid leukaemia can mimic typical blast crisis chromosome abnormalities or classic $t(9 ; 22)$ : a report of two cases. Br J Haematol 200 I, I I 3:439-442.

II. Weise A, Mrasek K, Fickelscher I, Claussen U, Cheung SW, Cai WW, Liehr T, Kosyakova N: Molecular definition of high-resolution multicolor banding probes: first within the human DNA sequence anchored FISH banding probe set. J Histochem Cytochem 2008, 56:487-493.

12. Fitzgerald PH, Morris CM: Complex chromosomal translocations in the Philadelphia chromosome leukemias. Serial translocations or a concerted genomic rearrangement? Cancer Genet Cytogenet 1991, 57:143-15I.

13. Nacheva E, Holloway T, Brown K, Bloxham D, Green AR: Philadelphia-negative chronic myeloid leukaemia: detection by FISH of BCR-ABL fusion gene localized either to chromosome 9 or chromosome 22. Br J Haematol | 994, 87:409-4I2.

14. Reid AG, Huntly BJP, Grace C, Green AR, Nacheva EP: Survival implications of molecular heterogeneity in variant Philadelphia-positive chronic myeloid leukaemia. Br J Haematol 2003, 1 21:419-427.

15. Claussen U, Michel S, Mühlig P, Westermann M, Grummt UW, Kromeyer-Hauschild K, Liehr T: Demystifying chromosome preparation and the implications for the concept of chromosome condensation during mitosis. Cytogenet Genome Res 2002, 98:136-146.

16. Liehr T, Heller A, Starke H, Rubtsov N, Trifonov V, Mrasek K, Weise $A$, Kuechler A, Claussen $U$ : Microdissection based high resolution multicolor banding for all 24 human chromosomes. Int J Mol Med 2002, 9:335-339.
Publish with Biomed Central and every scientist can read your work free of charge

"BioMed Central will be the most significant development for disseminating the results of biomedical research in our lifetime. "

Sir Paul Nurse, Cancer Research UK

Your research papers will be:

- available free of charge to the entire biomedical community

- peer reviewed and published immediately upon acceptance

- cited in PubMed and archived on PubMed Central

- yours - you keep the copyright
BioMedcentral 